\title{
Need of Interdisciplinary Researches and Publications with Ayurvedic Scientist: Valuable for Community and Sciences
}

\author{
Kore Sharayu Avinash* \\ Department of Dravyaguna, Sumatibhai Shah Ayurveda Mahavidhyalaya, India
}

*Corresponding author: Kore Sharayu Avinash, Professor and HOD, Department of Dravyaguna, Sumatibhai Shah Ayurveda Mahavidhyalaya, Hadapsar, Pune , India-411028

Submission: 眥 August 30, 2017; Published: 眥 November 13, 2017

\section{Introduction}

Interdisciplinary research (IDR) is a mode of research by teams or individuals that integrates information, data, techniques, tools, perspectives, concepts, and theories from two or more disciplines or bodies of specialized knowledge to advance fundamental understanding or to solve problems. Lack of good quality publication in peer review journal is very serious problem which brings denial into the mind of any researcher to accept its high reliability and applicability in health care. There are 69 Ayurveda colleges in Maharashtra and around 302 all over India offering post graduate courses in 3 to 14 subjects. In spite of such huge number of young Scientist available in field, the number of publications is very few in English language. However it should be kept in mind that some good literature and papers appear in regional languages, journal or magazines which has more applicability than those articles appear in peer review journals. The selected can be translated to further percolation of applied knowledge.

There is gradual and good change in Ayurvedic researches in last two decades. Due to networking facility and sharing of knowledge repetition of work up to certain extent can be avoided. But Publication of their research is very poor. There are possible causes. One is the improper guidance regarding scientific writing and another is appropriate use of language and grammar. Improper grammar and language becomes a hurdle to reach to the end user of knowledge. Due to hesitation and lack of confidence about acceptance of their write ups, so many good researches are still lying without Publication. Ayurvedic research scholars need to understand the rule of either Publish or Perish.

Publishing in good journals requires three Ps: Performance, Practice, and Persistence. Not only publication but citation is also equally important criteria. The three Cs: communication, collaboration, care are important. Along with these attributes; courage, compassion and commitment are also equally important to carry out good research.

List of few Ayurveda and related journals
a) Journal of Homeopathy \& Ayurvedic Medicine
b) International Journal of Research in Ayurveda and Pharmacy
c) Journal of Ayurveda and Holistic Medicine
d) Reviews of Progress
e) Journal of Ayurveda and Integrative Medicine
f) International Journal of Advanced Ayurveda, Yoga, Unani, Siddha and Homeopathy
g) Research in Plant Biology
h) Journal of Pharmacognosy and Phytochemistry
i) International Journal of Herbal Medicine
j) International Research Journal of Pharmacy
k) AYU international journal
l) Journal of Ayurveda and Integrated Medicine

The above list really excludes various Ayurvedic literature published in local languages. Ayurveda Patrika, Madhujeevan, Srujanchikitsa are few to mention in Marathi. Amruth, AyurVignyan are few publications from Kerala which may not available online but literature wise they are highly useful to nurture Ayurveda science be peer reviewed by Ayurveda experts.

There are many misconceptions about Ayurveda Science .some may consider that Ayurveda is herbal science. But one should remember that 'All Ayurveda is not herbal and all herbal is not Ayurveda'. Use of Ayurveda by global community is done to find the drug molecule of interest. Which is the conventional way of drug research; modern science is applying this methodology since 200 years. But now the modern science is facing problem of antibacterial resistance. Thus continuing the same methods may misutilize the Research funds with poor outcome. Pharmacogenomics is currently very popular science but its application in health care will take miles to go. At this stage Principles of Ayurveda pharmaceutical 
and treating the diseases must be thought of. Drugs can be designed according to same problems with varied Prakriti (Temperaments), season and different 10 such variables specified by Acharya Charak.

There are thousands of experimental herbal researches in Plant like Ashwagandha and Shatavari and many more. But whole drug extracts are not tested for their safety or efficacy as far as human clinical trials are concerned it may not stand in post market surveillance. It is out of question now that Ayurveda science has attracted researchers all over world to get novel output. But as an Ayurveda Scientist it is my opinion that instead of exploiting science in some way which is not very relevant to that particular science some modifications in research are required. Otherwise Ayurveda and drug for the science are blamed. The rules regarding its use according to particular season and proper timings as well as proper vehicle all look minor things but have greater impact as far as efficacy of drug is concerned. For e g. some drug is given with cow ghee as a vehicle for cancer treatment when tested in cancer cell line the ghee cannot be sued as vehicle or dosage form otherwise the cell get suffocated and dies.

Instead of using extract of drug various dosage forms recommended like kashaya (decoction), ghan (aqueous extract prepared by further drying of decoction) of Ayurveda drug can show minimal side effects. The hot and cold impact is highly sensitive issue in Ayurvedic pharmacology. Thus change of temperature in dosage form as cold and hot infusion can have altogether different impact in terms of Ayurvedic pharmaco-therapeutics. Principles of Ayurveda are strong which has made this science immortal in last 5000years or many more. Thus discussing and exchanging knowledge from other disciplines with Ayurveda Scientists can definitely improve Research protocol designing for quality research work which will reach to the society.

All the hurdles like lack of grant and Scholarships to Ayurvedic scientists is a major cause that researches may not fulfill the criteria for publications in good peer review journals. Same problems are faced with researchers in private Institutions. Research Scholar has to spend lot of time and energy in undergraduate as well as post graduate level as compared to any discipline form basic sciences. ICMR, DST from India and many more global institutes and Research foundations has strategies to support scholars from basic sciences very leniently as compared to narrow band for Ayurvedic scientists.

\section{Ayurveda}

For few researchers money becomes a major hurdle but for a few there is strong need of proper guidance and correct methodology. Improvement in both areas will benefit the Researchers and science equally.

The infrastructure facilities of Ayurveda colleges are basically hospital based. Ayurved Science is based on strong observation and interpretation of actual knowledge of Sharir (Structural and functional aspect based on principles of Panchmahabhoot and tridosh of Ayurveda) with logical thinking, knowledge of Nidan Panchak (Five aspect of diagnosis beginning form etiology and through knowledge of aushadh(Medicines and pharamcotherapeutics are sufficient to become an expertise of Ayurveda. But it needs supplementation of modern science knowledge if it has to be acceptable in globe to serve the community.

Pre-clinical and Para-clinical Post Graduate students of Ayurveda stream suffer a lot to complete their relevant dissertation with good quality researches. Basic research is very important for any science. The efforts student take must be appreciated. They with their respective guide and HOD go to various scientific laboratories to fulfill their needs and complete the work. The efforts of many institutions are wonderful. Some of them have a slight commercial view also. Only clinical trials are communicated with Ayurvedic hospital which may not have the basis of Ayurvedic research.

At this point it is felt that that part of students' contribution to innovative topics need some refinement and the work should not be left over at the stage but can be continued as further work which needs high skill and sophisticated instruments. If the researches are interdisciplinary they will have novel, feasible, good topic and would also contribute in either science.

In the context of biomedical research, globalization fundamentally reconfigures the ways in which health and illness are defined, evidence is generated, and interventions are prioritized. Considering the need of hour, quality researches in Ayurvedic field can add up to good contribution for society. Due to vast knowledge in each field the future researches needs to be collaborative for better outcome. It is highly recommended that students of Ayurveda should be considered as potential researchers and grant for them may be migrated from relevant available sources. Other Basic sciences, Pharmacy, and other relevant streams like agriculture and forest department should join hands for interdisciplinary research along with Ayurveda fraternity.

\section{Some areas of Research for interdisciplinary work}

Developing technical method to facilitate Balguti (Traditional method in preventive health on neonate to infant using simple various herbal drugs; keeping in mind their specific actions).The traditional method of making very fine paste by grinding the drug manually is tedious. The advantages are as follow.

A. Shelf life of whole drug is 6 times more than powdered drug (Only whole drugs are used).

B. Dose adjustment is possible considering day to day changes in physiology or minor complaint of child like cough, fever, flatulence, constipation, catarrhal conditions etc.

\section{Some hurdles}

a. Cleanliness of grinding stone is required.

b. Drying of each drug is required.

c. Shape of each drug is different.

d. Daily 5 to 1520 minutes are required for all process and giving it to child.

The rotational device carrying all above drugs in various holders where rotation of each drug can be set as per need and 
operation should be started with end product required as per need. This can prevent upto 80 to $90 \%$ lesser visits at Pediatrician for minor to major complaints.

Effective use of the above mention method can also be thought as Ayurvedic immunizing system which holds many drugs against various pathogens responsible to derange child health. Another unexplored field is to correlate various changes in biochemical parameters and electronic conductions like ECG, EEG, EMG and other such phenomena to understand dosh and dhatu dushti or Khavaigunya according to Ayurvedic diagnostic principles. This field is hardly explored. Difference in biological activities of various dosage form of same drug like swaras Kalka kwath, heem and phant should be explored. To see the effect of various temperature of these kalpanas on neurotransmitters and hormones which are considered very important in drug action potential.

Thus there are many such unexplored phenomena to understand them in scientific way. I would like to stress here that the traditional knowledge when packed in a newer way becomes much more costly, thus their use in current existing form also should be encouraged.
This will be service to all human in universe. Sushrutacharya, Father of Surgery while stressing need of knowledge of various allied sciences like Astronomy, astrology, Grammer, basic sciences available today, Metaphysics mentioned by other philosophers in Darshan Puran Veda etc and other ancient literature also helps to understand our science better.

Eg. Vrikshayurveda can give knowledge relevant in current era which can be useful in agronomy. Drugs from Ashwayurvda and hastiayurveda can be also screened to use in human and so on. Sushrut Samhita Chapter 40 of sutrasthan clearly mentions that knowledge of Ayurveda has been time tested and should be used for benefits of mankind. Knowledge can be tested but its use should not be stopped for wont of research since it is mentioned by Agam (Science which talks about only unbiased truth), and it is famous for its actions as well it gives the result and is evidence based. Though all researchers are open to understand and question their principles and then work to re asses it. Charakachayrya mentions Sharing of knowledge and testing it in team by experts can give unbiased knowledge. 